\title{
Viral lysis and nanoflagellate grazing as factors controlling diel variations of Synechococcus spp. summer abundance in coastal waters of Taiwan
}

\author{
An-Yi Tsai ${ }^{1, *}$, Gwo-Ching Gong ${ }^{1,2}$, Robert W. Sanders ${ }^{3}$, Kuo-Ping Chiang ${ }^{1}$, \\ Jun-Kai Huang ${ }^{1}$, Ya-Fan Chan ${ }^{4}$ \\ ${ }^{1}$ Institute of Marine Environmental Chemistry and Ecology, and ${ }^{2}$ Center of Excellence for Marine Bioenvironment and \\ Biotechnology, National Taiwan Ocean University, Keelung 202-24, Taiwan ROC \\ ${ }^{3}$ Department of Biology, Temple University, Philadelphia, Pennsylvania 19122, USA \\ ${ }^{4}$ Institute of Marine Biology, National Taiwan Ocean University, Keelung 202-24, Taiwan, ROC
}

\begin{abstract}
Diel variations in the protozoan grazing and viral-mediated mortality of Synechococcus spp. were simultaneously estimated using a modified dilution method in the coastal waters off Taiwan during 4 cruises in summer 2011. During the study period, the abundance of Synechococcus spp. showed a clear diel cycle and ranged from $1.2 \times 10^{4} \mathrm{cells} \mathrm{ml}^{-1}$ at 08:00 $\mathrm{h}$ to $9.8 \times 10^{4}$ cells $\mathrm{ml}^{-1}$ at midnight. The frequency of dividing cell (FDC) values were highest between afternoon and dusk and decreased to $<10 \%$ between 20:00 and 08:00 h. Synechococcus spp. specific growth rates varied during the experimental period from 0.025 to $0.033 \mathrm{~h}^{-1}$ and 0.050 to $0.085 \mathrm{~h}^{-1}$ at daytime and nighttime, respectively. Rates of Synechococcus spp. mortality due to nanoflagellate grazing averaged $0.031 \mathrm{~h}^{-1}$ during daytime and $0.041 \mathrm{~h}^{-1}$ at night. The estimated mortality due to viral lysis was between 0.011 and $0.019 \mathrm{~h}^{-1}$ during daytime and between 0.026 and $0.065 \mathrm{~h}^{-1}$ at night. Nanoflagellate grazing was the dominant cause of Synechococcus spp. mortality during daytime; however, mortality from viral lysis and nanoflagellate grazing was more balanced at night.
\end{abstract}

KEY WORDS: Synechococcus spp. $\cdot$ Modified dilution method $\cdot$ Viruses $\cdot$ Nanoflagellates

\section{INTRODUCTION}

The fate of primary production has important implications for food web structure and biogeochemical cycling. In oceanic communities, picoplankton often dominate phytoplankton biomass and productivity (Waterbury et al. 1986, Olson et al. 1990, Blanchot \& Rodier 1996, Agawin et al. 2000) and thus play a key role in marine carbon and nutrient cycles (Campbell et al. 1994). These picophytoplankton cells are not likely to sink due to their small size (Raven 1998), and grazing by nanoflagellates is frequently considered the major cause of mortality
(Sanders et al. 2000, Sherr \& Sherr 2002, Kimmance et al. 2007, Tsai et al. 2008, 2009). However, phytoplankton mortality from lysis has been described (Agusti et al. 1998, Alonso-Laita \& Agusti 2006), and viruses may also control picophytoplankton abundance through high lytic activities (Baudoux et al. 2006, 2008, Kimmance et al. 2007). The flow of matter and energy through the food web is different depending on whether cells are grazed or lysed (Fuhrman 1999). Grazed production is at least partly passed to higher trophic levels, whereas viral lysis recycles nutrients and carbon within the microbial loop (Gobler et al. 1997). 
Synechococcus spp. show distinct diel changes in abundance, with higher division rates at dusk (Dolan \& Šimek 1999, Vaulot \& Marie 1999, Christaki et al. 2002, Tsai et al. 2009) and maximum abundances at night (Christaki et al. 2002, Tsai et al. 2009). Christaki et al. (2002) reported that the ingestion rates of heterotrophic nanoflagellates (HNF) were highest at night and declined during the daytime. Furthermore, the highest ingestion rates by nanoflagellates occurred after Synechococcus spp. cell division (Dolan \& Šimek 1999, Tsai et al. 2009). These results are consistent with the control of Synechococcus spp. via consumption by heterotrophic and/or pigmented nanoflagellates.

Another potential source of cyanobacterial mortality is lysis by viruses (Suttle 2000). Cyanophages that infect Synechococcus spp. are often abundant, with concentrations coupled to those of their putative hosts (Wang \& Chen 2004), but viral lysis of Synechococcus spp. is not always observed or is sometimes low compared with viral lysis of eukaryotic phytoplankton (Baudoux et al. 2007, 2008). Suttle (2000) suggested that viral infection and lysis of Synechococcus spp. vary during the diel cycle, akin to the observed periodicity for protistan ingestion noted above. This could affect determinations of viral-induced mortality.

The interplay between viruses and nanoflagellates in the control of aquatic prokaryotes is still poorly understood (Pernthaler 2005, Miki \& Jacquet 2008). Bacterivory by pigmented nanoflagellates (PNF) appear to be the underlying biological factor regulating diel variations in Synechococcus spp. in coastal water of the subtropical western Pacific during summer (Tsai et al. 2009). However, no data exist on the effect of viral-mediated mortality for Synechococcus spp. for this area. The goal of the present study is to simultaneously compare the roles of viral lysis and nanoflagellate bacterivory in the diel variability of Synechococcus spp. in these waters during summer.

\section{MATERIALS AND METHODS}

\section{Sampling}

Samples were collected once a month from May to August 2011 (30 May, 27 June, 21 July and 23 August) at an established coastal station $\left(25^{\circ} 09.4^{\prime} \mathrm{N}\right.$, $\left.121^{\circ} 46.3^{\prime} \mathrm{E}\right)$ along a rocky shore in northeastern Taiwan (Fig. 1). The environment of this site has already been described, based on data gathered from 1999 to 2001 (Tsai et al. 2005).
Samples for the enumeration of Synechococcus spp., heterotrophic nanoflagellates (HNF), pigmented nanoflagellates (PNF) and viruses were collected at $2 \mathrm{~h}$ intervals for $24 \mathrm{~h}$ (for $12 \mathrm{~h}$ in May). On each sampling day, seawater was collected twice for modified dilution experiments, from 08:00 to 09:00 $\mathrm{h}$ in the morning and 20:00 to 21:00 $\mathrm{h}$ in the evening (local time). The water temperature was measured immediately after the sampling bucket was cast, and all samples were brought to the laboratory within $30 \mathrm{~min}$.

\section{Dilution experiments}

We estimated viral lysis and nanoflagellate grazing rates using a modified technique of parallel dilution experiments: a 'standard' set that reduces grazers and a set that reduces both grazers and viruses (Evans et al. 2003). Filter holders and incubation bottles were acid-cleaned with $10 \% \mathrm{HCl}$ and rigorously rinsed with Milli-Q water. To prepare the 'standard' diluent, the natural sample was passed through $10 \mu \mathrm{m}$ mesh and then filtered through $47 \mathrm{~mm}$ Nuclepore filters (type PC, pore size of $0.2 \mu \mathrm{m}$ ). A filtered seawater sample $(<10 \mu \mathrm{m})$ was then diluted with the $0.2 \mu \mathrm{m}$ filtered seawater in a 4-point dilution series consisting of $25,50,75$ and $100 \%$ seawater $(<10 \mu \mathrm{m})$. The series was incubated in $50 \mathrm{ml}$ polycarbonate bottles for $8 \mathrm{~h}$ under continuous illumination $(\sim 150 \mu \mathrm{mol}$ quanta $\mathrm{m}^{-2} \mathrm{~s}^{-1}$ ) in thermo-controlled incubators $\left(24^{\circ} \mathrm{C}\right.$ in May and $28^{\circ} \mathrm{C}$ in the other months). The size fractionation used for grazers $(<10 \mu \mathrm{m})$ was chosen based on previous studies at this site to eliminate ciliates but not nanoflagellates (Tsai et al. 2011). An

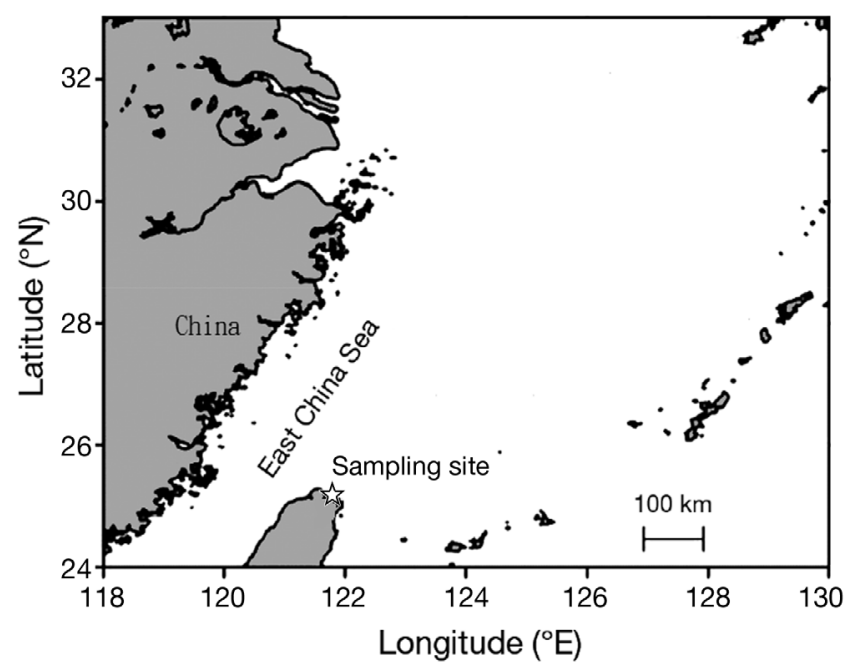

Fig. 1. Sampling site ( $(\hat{)})$ in coastal waters of the western subtropical Pacific 
additional dilution series, using $10 \mathrm{kDa}$ filtered seawater in place of $0.2 \mu \mathrm{m}$ filtered water, modified both grazing and viral mortalities. The net growth rate of Synechococcus spp. $\left(k, \mathrm{~h}^{-1}\right)$ was calculated for each sample based on microscopic cell counts at the start and the end of the experiment $\left(N_{t 0}\right.$ and $\left.N_{t}\right)$ assuming exponential growth (Landry \& Hassett 1982):

$$
k=\ln \left(N_{\mathrm{t}} / N_{t 0}\right) /\left(t-t_{0}\right)
$$

The regression coefficient of the apparent growth rate versus dilution factor for the $0.2 \mu \mathrm{m}$ dilution series, though usually interpreted as protistan grazing $\left(m_{\mathrm{g}}\right)$ (Landry \& Hassett 1982), actually includes viral mortality $\left(m_{\mathrm{v}}\right)$ because most viruses pass through a $0.2 \mu \mathrm{m}$ pore (Evans et al. 2003). However, when virus-free seawater (10 kDa filters) is used as a diluent, the regression reflects release from both grazing and viral mortality $\left(m_{\mathrm{g}}+m_{\mathrm{v}}\right)$, and a direct estimate of viral mortality for Synechococcus spp. can be obtained from the difference in the slopes of the regression lines between the 2 dilution series.

\section{Viral, Synechococcus spp. and nanoflagellate abundance counts}

Viruses, Synechococcus spp. and nanoflagellates were counted using an epifluorescence microscope (Nikon Optiphot-2) at $1000 \times$ magnification. Viruses were processed with a slight modification of a protocol described by Noble \& Fuhrman (1998). Briefly, samples from 0.5 to $1 \mathrm{ml}$ were filtered on Anodisc filters $(0.02 \mu \mathrm{m}$ pore size, Whatman) backed by $0.45 \mu \mathrm{m}$ pore size Millipore filters. The samples were then placed on drops of SYBR Green I (Molecular Probes) solution diluted at 1:400 in TE buffer (10 mM Tris-HCl, 1 mM EDTA, $\mathrm{pH}$ 8.0) and stained for 15 min in the dark. The membranes were then placed on glass slides and treated with $25 \mu \mathrm{l}$ of $50 \%$ glycerol and $50 \%$ PBS buffer $(0.85 \% \mathrm{NaCl}$, $0.05 \mathrm{M} \mathrm{NaH}_{2} \mathrm{PO}_{4}, \mathrm{pH}$ 7.5) containing $0.1 \% p$ phenylenediamine as antifade and mounting agents. Subsamples of 1 to $2 \mathrm{ml}$ or $20 \mathrm{ml}$ were filtered onto $0.2 \mu \mathrm{m}$ or $0.8 \mu \mathrm{m}$ black Nuclepore filters for Synechococcus spp. and nanoflagellates, respectively. Samples for counting nanoflagellates were stained with DAPI at a final concentration of $1 \mu \mathrm{g}$ $\mathrm{ml}^{-1}$ (Porter \& Feig 1980); PNF and HNF were distinguished based on the presence or absence of chlorophyll autofluorescence. Synechococcus spp. were identified by their orange autofluorescence under blue excitation light. Dividing cells of Synechococcus spp. were also enumerated, and the fre- quency of dividing cells (FDC) was examined. To obtain reliable estimates of abundance, we counted 30, 30 and 50 fields of view for viruses, Synechococcus spp. and nanoflagellates, respectively.

\section{Statistical analysis}

Least-square regression analysis was performed to determine the relationship between the Synechococcus spp. growth rate and fraction of $10 \mathrm{kDa}$ or $0.2 \mu \mathrm{m}$ dilution series. The significance of the regression lines was tested using an analysis of variance (ANOVA). The significance of differences between the slopes of the $10 \mathrm{kDa}$ and $0.2 \mu \mathrm{m}$ dilution series was determined using an $F$-test. When the slopes were significantly different, the magnitude of viral mortality was assessed. STATISTICA 7.0 software was used for all statistical operations.

\section{RESULTS}

\section{Diel variations of Synechococcus spp., nanoflagellate and viral concentrations}

The sea surface temperature at the coastal station was generally highest at 14:00 h and cooler at night for all sampling dates, though the temperature in May was cooler than that of the other months investigated (Fig. 2A). FDC values showed a strong diel variation pattern, with the greatest abundance of dividing cells present between afternoon and dusk and decreasing to $<10 \%$ between $20: 00 \mathrm{~h}$ and 08:00 h (Fig. 2B). The highest FDC was $~ 50 \%$ in the June and August samples compared to 30 to $35 \%$ in May and July (Fig. 2B). The greatest diel change in the abundance of Synechococcus spp. occurred in July when the population size increased from $1.2 \times$ $10^{4}$ cells ml ${ }^{-1}$ at $08: 00 \mathrm{~h}$ to $9.8 \times 10^{4}$ cells ml ${ }^{-1}$ at midnight (Fig. 2C). During the other months, the diel change in Synechococcus spp. abundance had a reduced amplitude, with the highest values $\left(5.8 \times 10^{4}\right.$ cells $\mathrm{ml}^{-1}$ ) recorded at 20:00 $\mathrm{h}$ and gradually decreasing through the night (Fig. 2C).

HNF and PNF abundance ranged from $0.45 \times 10^{3}$ to $1.51 \times 10^{3} \mathrm{cells} \mathrm{ml}^{-1}$ and $0.58 \times 10^{3}$ to $2.80 \times 10^{3}$ cells $\mathrm{ml}^{-1}$, respectively (Fig. 3A,B). PNF showed clear diel patterns in abundance, with the highest values recorded at dusk (August) or night (June and July) during the study period (Fig. 3B). No diel rhythm was evident for either HNF or viral abundance (Fig. 3A,C). 

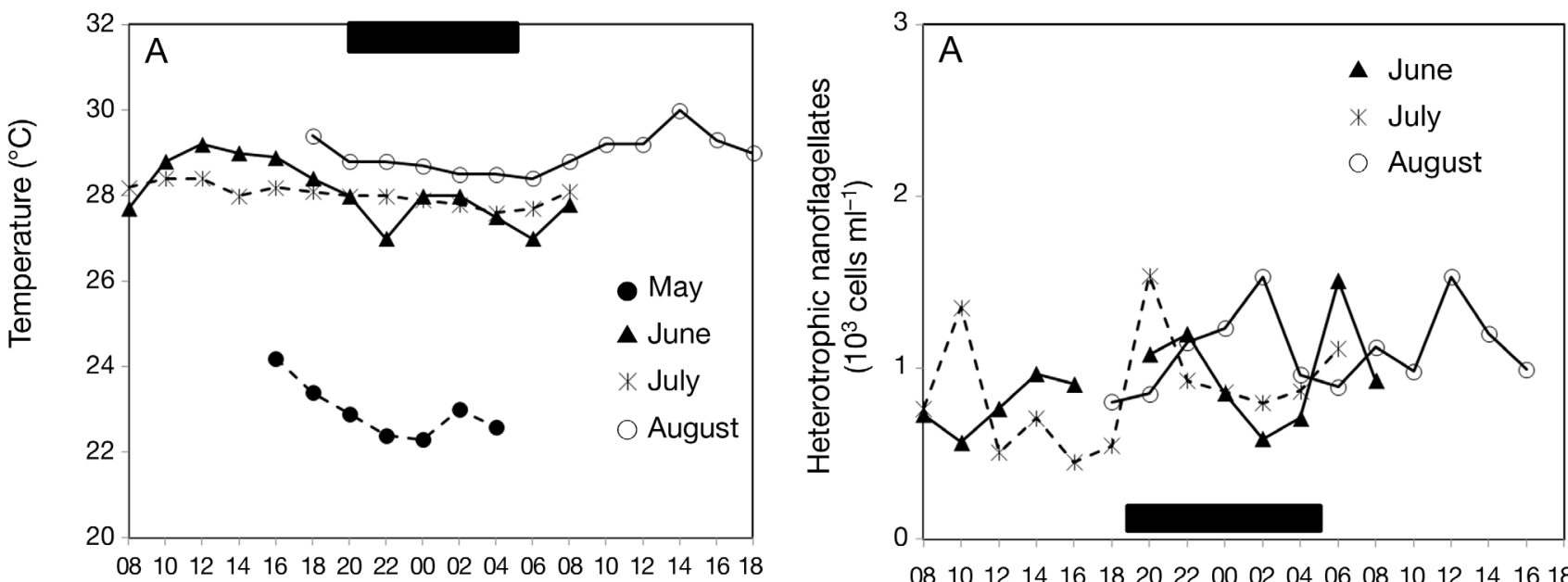

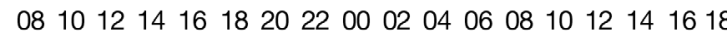

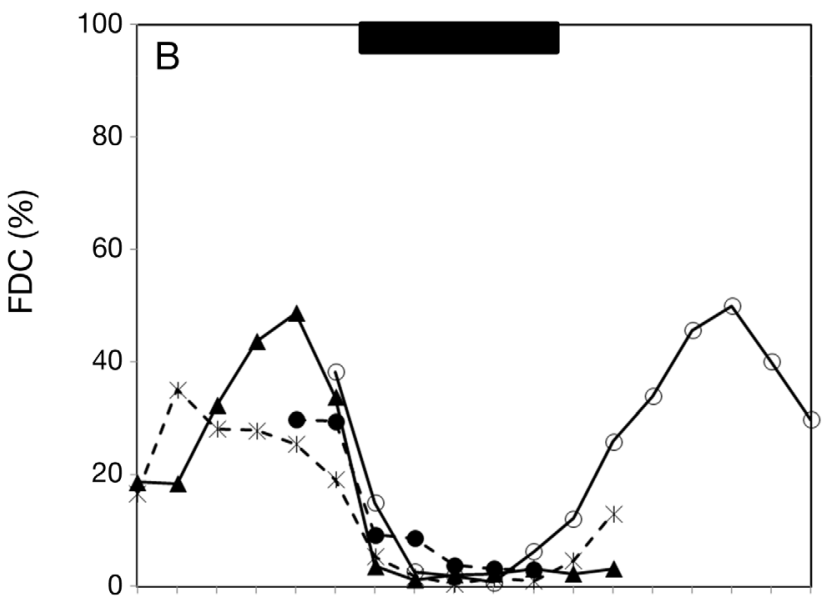

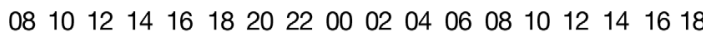
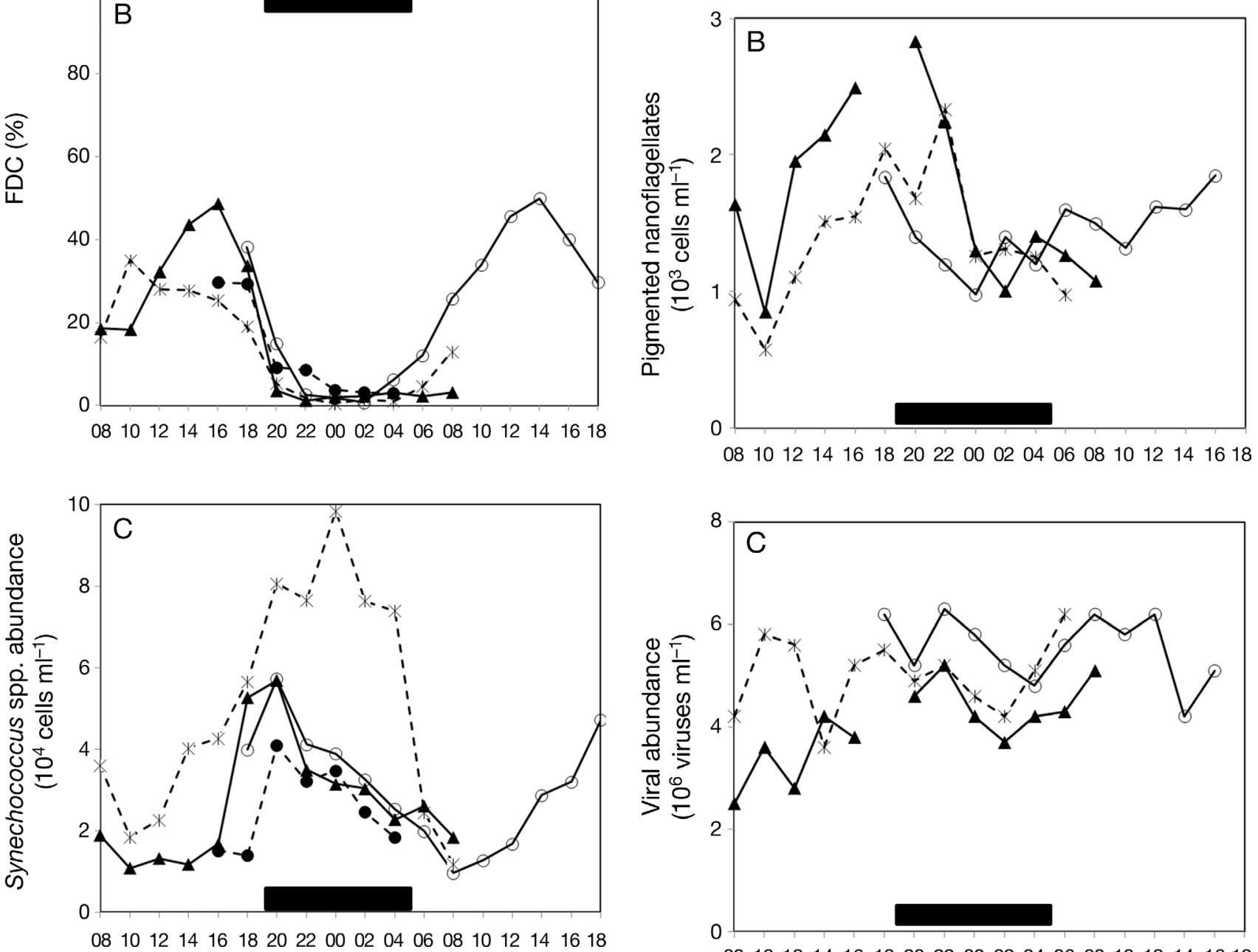

Time (h)

Fig. 2. Diel variations of (A) surface water temperature, (B) frequency of dividing cell (FDC) and (C) Synechococcus spp. abundance between May and August 2011. The black bar represents the dark period

\section{Time $(\mathrm{h})$}

Fig. 3. Diel variations in (A) heterotrophic nanoflagellate, (B) pigmented nanoflagellate and $(\mathrm{C})$ viral abundance between June and August 2011. Data not available for 18 June 


\section{Synechococcus spp. growth and mortality in dilution experiments}

The $y$-intercepts of the regression lines (Synechococcus spp. specific growth rates) for the $0.2 \mu \mathrm{m}$ and $10 \mathrm{kDa}$ fractionated series were, on average, 0.006 and $0.029 \mathrm{~h}^{-1}$ for the daytime experiments and 0.011 and $0.063 \mathrm{~h}^{-1}$ for the nighttime experiments (Table 1). The regression coefficients (slopes), which represent Synechococcus spp. mortality, ranged from 0.025 to $0.034 \mathrm{~h}^{-1}$ and 0.044 to $0.052 \mathrm{~h}^{-1}$ for the $0.2 \mu \mathrm{m}$ and $10 \mathrm{kDa}$ fractionated series, respectively, in daytime experiments (Table 1); there were significant differences between the slopes for the different fractionations $(p<0.05)$. For nighttime experiments, the values of regression coefficients ranged from 0.035 to $0.047 \mathrm{~h}^{-1}$ and 0.061 to $0.105 \mathrm{~h}^{-1}$ for the $0.2 \mu \mathrm{m}$ and $10 \mathrm{kDa}$ fractionated series, respectively (Table 1 ). The differences between the slope values indicated that Synechococcus spp. mortality due to viral lysis $\left(m_{\mathrm{v}}\right)$ ranged from 0.011 to $0.019 \mathrm{~h}^{-1}$ and 0.026 to $0.065 \mathrm{~h}^{-1}$ for daytime and nighttime experiments, respectively; the nighttime values were always higher than those

Table 1. Linear regression analysis of $0.2 \mu \mathrm{m}$ and $10 \mathrm{kDa}$ dilution series. Standard errors in parentheses. ${ }^{*}$ Regressions with significant $(p<0.05)$ mortality slopes and differences between the slopes of the $0.2 \mu \mathrm{m}$ and $10 \mathrm{kDa}$ dilution series. Samples collected only at night in May

\begin{tabular}{|c|c|c|c|c|c|}
\hline Period & Fraction & $\begin{array}{c}\text { Growth rate } \\
\mu\left(\mathrm{h}^{-1}\right)\end{array}$ & $\begin{array}{c}\text { Grazing rate } \\
m_{\mathrm{g}}\left(\mathrm{h}^{-1}\right)\end{array}$ & $\begin{array}{l}\text { Lysis rate } \\
m_{\mathrm{v}}\left(\mathrm{h}^{-1}\right)\end{array}$ & $\begin{array}{l}\text { Ratio of lysis (\%) } \\
\quad\left(m_{\mathrm{v}} /\left[m_{\mathrm{g}}+m_{\mathrm{v}}\right]\right)\end{array}$ \\
\hline \multicolumn{6}{|l|}{ May } \\
\hline \multirow[t]{2}{*}{ Day } & $0.2 \mu \mathrm{m}$ & - & - & - & - \\
\hline & $10 \mathrm{kDa}$ & - & - & - & - \\
\hline \multirow{2}{*}{ Night } & $0.2 \mu \mathrm{m}$ & $0.013^{*}(0.004)$ & $0.035(0.008)$ & & \\
\hline & $10 \mathrm{kDa}$ & $0.05^{*}(0.003)$ & & $0.026^{*}(0.006)$ & 42.6 \\
\hline \multicolumn{6}{|l|}{ June } \\
\hline Day & $\begin{array}{l}0.2 \mu \mathrm{m} \\
10 \mathrm{kDa}\end{array}$ & $\begin{array}{l}0.009 *(0.005) \\
0.025^{*}(0.003)\end{array}$ & $0.034(0.007)$ & $0.018^{*}(0.007)$ & 34.6 \\
\hline Night & $\begin{array}{l}0.2 \mu \mathrm{m} \\
10 \mathrm{kDa}\end{array}$ & $\begin{array}{l}0.001^{*}(0.011) \\
0.085^{*}(0.024)\end{array}$ & $0.04(0.011)$ & $0.065^{*}(0.026)$ & 61.9 \\
\hline \multicolumn{6}{|l|}{ July } \\
\hline Day & $\begin{array}{l}0.2 \mu \mathrm{m} \\
10 \mathrm{kDa}\end{array}$ & $\begin{array}{l}0.001 *(0.006) \\
0.028 *(0.008)\end{array}$ & $0.034(0.003)$ & $0.011^{*}(0.006)$ & 24.4 \\
\hline Night & $\begin{array}{l}0.2 \mu \mathrm{m} \\
10 \mathrm{kDa}\end{array}$ & $\begin{array}{l}0.018^{*}(0.006) \\
0.063^{*}(0.009)\end{array}$ & $0.047(0.005)$ & $0.043^{*}(0.008)$ & 47.8 \\
\hline \multicolumn{6}{|l|}{ August } \\
\hline Day & $\begin{array}{l}0.2 \mu \mathrm{m} \\
10 \mathrm{kDa}\end{array}$ & $\begin{array}{l}0.009^{*}(0.003) \\
0.033^{*}(0.006)\end{array}$ & $0.025(0.002)$ & $0.019^{*}(0.006)$ & 43.2 \\
\hline Night & $\begin{array}{l}0.2 \mu \mathrm{m} \\
10 \mathrm{kDa}\end{array}$ & $\begin{array}{l}0.012^{*}(0.004) \\
0.055^{*}(0.006)\end{array}$ & $0.041(0.003)$ & $0.038^{*}(0.007)$ & 48.1 \\
\hline \multicolumn{6}{|l|}{ Mean } \\
\hline Day & $\begin{array}{l}0.2 \mu \mathrm{m} \\
10 \mathrm{kDa}\end{array}$ & $\begin{array}{l}0.006(0.006) \\
0.029(0.004)\end{array}$ & $0.031(0.005)$ & $0.016(0.004)$ & $34(9.4)$ \\
\hline Night & $\begin{array}{l}0.2 \mu \mathrm{m} \\
10 \mathrm{kDa}\end{array}$ & $\begin{array}{l}0.011(0.007) \\
0.063(0.015)\end{array}$ & $0.041(0.005)$ & $0.043(0.016)$ & $51.2(8.3)$ \\
\hline
\end{tabular}

for the daytime experiments ( $t$-test, $\mathrm{p}<0.05)$ (Table 1$)$. Rates of Synechococcus spp. mortality due to nanoflagellate grazing $\left(m_{\mathrm{g}}\right)$ determined from the standard $0.2 \mu \mathrm{m}$ fractionated series varied from 0.025 to $0.034 \mathrm{~h}^{-1}$ and 0.035 to $0.047 \mathrm{~h}^{-1}$ at daytime and nighttime, respectively (Table 1), and also showed higher values at night ( $t$-test, $p<0.05)$. In the present study, nanoflagellate grazing was responsible for most of the Synechococcus spp. mortality ( $66 \%$ of the total) during daytime. However, mortality due to viral lysis increased in relative importance and was essentially equal to nanoflagellate grazing mortality at night $(51.2 \%$ vs. $48.8 \%$ of the total mortality) (Table 1$)$. Furthermore, grazing rate and viral lysis were positively correlated with Synechococcus spp. growth (grazing: $r=0.66, p<0.05$; viral lysis: $r=0.97, p<0.05$ ).

\section{DISCUSSION}

Several methods have been used to estimate viral mortality of components of the microbial food web. These methods include tracking changes in viral abundance, production or decay rate (Heldal \& Bratbak 1991, Wilhelm et al. 2002) and measuring the frequency of virus-infected bacterial cells (Proctor et al. 1993, Binder 1999). These methods use several assumptions about latent periods and/or burst sizes for viruses, and one advantage of the modified dilution method used here is that it gives insight into the quantitative significance of both viral lysis and grazing without the need for conversion factors (Jacquet et al. 2005).

The use of parallel dilution series involving the reduction of both viruses and microzooplankton (Evans et al. 2003) was previously used to estimate the mortality of the haptophyte Phaeocystis globosa (Scherffel) in temperate coastal waters (Baudoux et al. 2006), bacterioplankton in a mesotrophic lake (Jacquet et al. 2005), picophytoplankton in the North Sea (Baudoux et al. 2008) and assorted microbial groups in an estuary of the Gulf of Mexico (Ortmann et al. 2011). A modifica- 
tion of the approach identified significant viralinduced mortality in bacterial populations off coastal Japan (Taira, et al. 2009). However, studies examining the relative importance of virus- and grazinginduced mortality in photosynthetic prokaryotes are still relatively rare (Baudoux et al. 2007, 2008, Ortmann et al. 2011). To our knowledge, the present study is the first to assess these components of Synechococcus spp. mortality together in the subtropical Pacific Ocean. Our data suggest that nanoflagellate grazing was the dominant cause of Synechococcus spp. mortality during daytime in this area, but viral lysis also was notable, especially at nighttime. These results are in contrast to previous studies in oligotrophic environments that consistently reported low viral infection rates and/or mortality for Synechococcus spp. (Suttle \& Chan 1994, Garza \& Suttle 1998, Baudoux et al. 2007, Baudoux et al. 2008).

The original dilution protocol was designed to determine the grazing of phytoplankton, and nutrient amendment was suggested to ensure that phytoplankton growth rates were independent of the dilution effect (Landry \& Hassett 1982). However, some more recent studies question the efficacy of this part of the procedure, especially for the modified method that also examines viral mortality. Worden \& Binder (2003) reported that the addition of nutrients stimulated microzooplankton-induced mortality rates of cyanobacteria in oligotrophic environments, leading to an overestimation of microzooplankton grazing rates. This was probably due to improvement of food quality of the cyanobacteria cells. Addition of nutrients also was reported to lead to an increase in viral burst size, thereby increasing viral production (Weinbauer et al. 2003), which could lead to an overestimation of viral-induced mortality. Kimmance \& Brussaard (2010) also recommend against nutrient addition in dilution experiments because of the potential to produce unnatural growth rates. For these reasons, nutrients were not added to the incubations in the present study.

A key factor for the utility of any of the dilution methods is the accuracy of the apparent prey/host growth rate measurements that determine the slope and intercept of the regression. Some previous studies suggested that dilution in virus-free water reduces the growth rates of picophytoplankton, including Synechococcus spp. (Suttle 2000, Kimmance et al. 2007). Explanations for these observations included the possibility that Synechococcus spp. growth was stimulated by enhanced recycling of nutrients due to viral lysis of hosts in seawater containing viruses $(0.2 \mu \mathrm{m}$ diluent) compared to the virus-free water (Kimmance et al. 2007). Weinbauer et al. (2011) also provided persuasive evidence that the presence of active viruses stimulated Synechococcus spp. growth. In our study, however, we observed higher Synechococcus spp. growth rates in the $10 \mathrm{kDa}$ than in the $0.2 \mu \mathrm{m}$ series (Table 1), as did Baudoux et al. $(2007,2008)$, which suggests that factors besides viral lysis were stimulating picophytoplankton growth rates. Nonetheless, if the relatively high viral mortality that we observed was stimulating growth in the $0.2 \mu \mathrm{m}$ diluent series but not in the $10 \mathrm{kDa}$ diluent series, then the maximum Synechococcus spp. growth may have been even greater than the regression predicted. This could partly explain why the combined grazing and viral mortality always exceeded Synechococcus spp. growth in our incubations (Table 1). Fluctuations in the balance of growth and mortality are common, but the consistently higher mortality that we observed in our study is obviously unsustainable in the long term. To compare the rate measurements to observed net changes in abundance, we calculated the net growth rate as $\mu_{\text {net }}=\mu-\left(\mathrm{m}_{\mathrm{g}}+\mathrm{m}_{\mathrm{v}}\right)$. For the 4 nighttime analyses (Table 1 ), the $\mu_{\text {net }}$ estimates were negative and correspond with the observed decrease in Synechococcus spp. abundance (Fig. 2C). However, the $\mu_{\text {net }}$ estimates were also negative for the daytime analyses, suggesting that the dilution method may underestimate growth or overestimate the grazing or lysis rate. A possible factor that may have contributed to an underestimation of Synechococcus spp. production is the temperature during daytime. Previous studies revealed temperature as an important parameter affecting growth of Synechococcus spp. (Chang et al. 1996, Tsai et al. 2005). In the June and August experiments, the thermo-controlled incubators were as much as $2^{\circ} \mathrm{C}$ cooler than the maximum sea surface temperature (Fig. 2A), which would have reduced Synechococcus spp. growth rates in those experiments. Furthermore, an experimental study by Pradeep Ram \& Sime-Ngando (2010) inferred that lysogeny tends to occur during periods of poor host cell abundance. Thus, in the viral dilution study, it is likely that the estimate of lysis in the more diluted treatment ( 25 to $50 \%$ fraction seawater dilution) was affected and the Synechococcus spp. growth rates were underestimated in our incubated samples.

Synechococcus spp. often exhibit a clear diel pattern, with higher division rates at dusk resulting in maximum abundance at night (Dolan \& Šimek 1999, Christaki et al. 2002, Tsai et al. 2005, 2009). Those investigations, including one at the same site as that sampled in our study (Tsai et al. 2009), suggested that 
the diel fluctuations of Synechococcus spp. abundance resulted from differential consumption by nanoflagellates. By using relatively short incubation periods, we were able to address the question of diel changes in grazing using a dilution method and also found higher feeding rates at night than during the day (Table 1). Tsai et al. (2009) suggested that size-selective feeding was the basis of the diurnal differences in ingestion of Synechococcus spp. by nanoflagellates. This was based on correlation of the higher grazing rates with the shift from larger dividing Synechococcus cells (daytime) to smaller non-dividing cells at night (Tsai et al. 2009) and a recognition that protistan grazers can exhibit a preference for certain prey size and type (e.g. Epstein \& Shiaris 1992).

We also attribute significant mortality of Synechococcus spp. at our study site to viruses and note a greater effect of viruses at nighttime (Table 1). The exact causes for the periodicity of viral lysis require further investigation. However, viral infection rates are density dependent (Fuhrman 1999), and the abundance of Synechococcus spp. was higher at nighttime than during the day (Fig. 2C). We propose that the higher Synechococcus spp. abundance led to increased viral infection and lysis at night. The lower Synechococcus spp. abundance (average of $2.2 \times 10^{4}$ cells $\mathrm{ml}^{-1}$ ) during the daytime of our study raises the possibility that the population size was below a threshold host concentration necessary for viral infection, as was suggested for other populations of Synechococcus spp. by Suttle \& Chan (1994). Threshold host abundances for successful virus infection have also been proposed for bacteria (Steward et al. 1992, Weinbauer \& Peduzzi 1994) and the coccolithophore Emiliania huxleyi (Jacquet et al. 2002). Furthermore, a previous study showed that the length of the lytic cycle (turnover time) is usually tightly coupled with the growth rate of the bacteria (Weinbauer 2004). In the present study, viral lysis was significantly and positively correlated with Synechococcus spp. growth rate (data not shown), and the effects of diel variations of Synechococcus spp. growth rate on viral lysis cannot be excluded.

Another non-exclusive factor contributing to diel differences in Synechococcus spp. mortality is ultraviolet radiation (UVR). UVR could have direct effects on Synechococcus spp., but it also causes significant damage to viruses (e.g. Winter et al. 2004, Yuan et al. 2011) and inhibits protistan feeding (Ochs 1997). Because UVR-induced damage decreases with diminishing daylight, its inhibition of viruses and grazing are also likely to decrease towards nighttime.
The interactions between viruses and grazers and their effects on picoplankton are probably very complex (Miki \& Jacquet 2008) and could include various antagonistic or synergistic effects (Sime-Ngando \& Pradeep Ram 2005). For example, nanoflagellates can directly reduce viral abundance and infectivity through direct consumption of viruses or by grazing preferentially on viral-infected cells (Bettarel et al. 2005). Though our study did not directly address these complexities, it does suggest that protistan grazing and viral infections interact to modify picoplankton primary production in an oligotrophic environment.

Our data reinforce the view that the abundance of Synechococcus spp. exhibited a clear diel pattern during summer in the western subtropical Pacific Ocean. The results confirmed that nanoflagellate grazing was a significant cause of Synechococcus spp. mortality, but viral lysis was also an important source of mortality, especially at nighttime. Future research is necessary to further evaluate the ecological importance and interactions of viral lysis versus grazing as agents of diel periodicity in picophytoplankton biomass and production in the subtropical marine environment.

Acknowledgements. This study was supported by a grant (NSC 100-2611-M-019-009) from the National Science Council, ROC.

\section{LITERATURE CITED}

Agawin NSR, Duarte CM, Agustí S (2000) Nutrient and temperature control of the contribution of picoplankton to phytoplankton biomass and production. Limnol Oceanogr 45:591-600

Agusti S, Satta MP, Mura MP, Benavent E (1998) Dissolved esterase activity as a tracer of phytoplankton lysis: evidence of high phytoplankton lysis rates in the northwestern Mediterranean. Limnol Oceanogr 43:1836-1849

Alonso-Laita P, Agusti S (2006) Contrasting patterns of phytoplankton viability in the subtropical NE Atlantic Ocean. Aquat Microb Ecol 43:67-78

Baudoux AC, Noordeloos AAM, Veldhuis MJW, Brussaard CPD (2006) Virally induced mortality of Phaeocystis globosa during two spring blooms in temperate coastal waters. Aquat Microb Ecol 44:207-217

- Baudoux AC, Veldhuis MJW, Witte HJ, Brussaard CPD (2007) Viruses as mortality agents of picophytoplankton in the deep chlorophyll maximum layer during IRONAGES III. Limnol Oceanogr 52:2519-2529

- Baudoux AC, Veldhuis MJW, Noordeloos AAM, van Noort G, Brussaard CPD (2008) Estimates of virus- vs. grazing induced mortality of picophytoplankton in the North Sea during summer. Aquat Microb Ecol 52:69-82

Bettarel Y, Sime-Ngando T, Bouvy M, Arfi R, Amblard C (2005) Low consumption of virus-sized particles by het- 
erotrophic nanoflagellates in two lakes of the French Massif Contral. Aquat Microb Ecol 39:205-209

- Binder B (1999) Reconsidering the relationship between virally induced bacterial mortality and frequency of infected cells. Aquat Microb Ecol 18:207-215

Blanchot J, Rodier M (1996) Picophytoplankton abundance and biomass in the western tropical Pacific Ocean during the 1992 EI Niño year: results from flow cytometry. DeepSea Res I 43:877-895

$>$ Campbell L, Nolla HA, Vaulot D (1994) The importance of Prochlorococcus to community structure in the central North Pacific Ocean. Limnol Oceanogr 39:954-961

$>$ Chang J, Chung CC, Gong GC (1996) Influences of cyclones on chlorophyll a concentration and Synechococcus abundance in a subtropical western Pacific coastal ecosystem. Mar Ecol Prog Ser 140:199-205

> Christaki U, Courties C, Karayanni H, Giannakouron A, Maravelias C, Kormas AK, Lebaron P (2002) Dynamic characteristics of Prochlorococcus and Synechococcus consumption by bacterivorous nanoflagellates. Microb Ecol 43:341-352

- Dolan JR, Šimek K (1999) Diel periodicity in Synechococcus populations and grazing by heterotrophic nanoflagellates: analysis of food vacuole contents. Limnol Oceanogr 44:1565-1570

- Epstein SS, Shiaris MP (1992) Size selective grazing of coastal bacterioplankton by natural assemblages of pigmented flagellates, colourless flagellates, and ciliates. Microb Ecol 23:211-225

$>$ Evans C, Archer SD, Jacquet S, Wilson WH (2003) Direct estimates of the contribution of viral lysis and microzooplankton grazing to the decline of a Micromonas spp. population. Aquat Microb Ecol 30:207-219

Fuhrman JA (1999) Marine viruses and their biogeochemical and ecological effects. Nature 399:541-548

> Garza DR, Suttle CA (1998) The effect of cyanophages on the mortality of Synechococcus spp. and selection for UV resistant viral communities. Microb Ecol 36:281-292

Gobler CJ, Hutchins DA, Fisher NS, Cosper EM, SañudoWilhelmy SA (1997) Release and bioavailability of C, N, $\mathrm{P}$, Se and Fe following viral lysis of a marine chrysophyte. Limnol Oceanogr 42:1492-1504

> Heldal M, Bratbak G (1991) Production and decay of viruses in aquatic environments. Mar Ecol Prog Ser 72:205-212

> Jacquet S, Hedal M, Iglesias-Rodriguez D, Larsen A, Wilson W, Bratbak G (2002) Flow cytometric analysis of an Emiliania huxleyi bloom terminated by viral infection. Aquat Microb Ecol 27:111-124

Jacquet S, Domaizon I, Personnic S, Sriram A and others (2005) Estimates of protozoan- and viral-mediated mortality of bacterioplankton in Lake Bourget (France). Freshw Biol 50:627-645

Kimmance SA, Brussaard CPD (2010) Estimation of viralinduced phytoplankton mortality using the modified dilution method. In: Wilhelm S, Weinbauer $\mathrm{M}$, Suttle $\mathrm{C}$ (eds) Manual of aquatic viral ecology. American Society of Limnology and Oceanography, Waco, TX, p 65-73

$>$ Kimmance SA, Wilson WH, Archer SD (2007) Modified dilution technique to estimate viral versus grazing mortality of phytoplankton: limitations associated with method sensitivity in natural waters. Aquat Microb Ecol 49: 207-222

> Landry MR, Hassett RP (1982) Estimating the grazing impact of marine microzooplankton. Mar Biol 67: 283-288
Miki T, Jacquet S (2008) Complex interactions in the microbial world: underexplored key links between viruses, bacteria and protozoan grazers in aquatic environments. Aquat Microb Ecol 51:195-208

> Noble RT, Fuhrman JA (1998) Use of SYBR Green I for rapid epifluorescence counts of marine viruses and bacteria. Aquat Microb Ecol 14:113-118

> Ochs CA (1997) Effects of UV radiation on grazing by two marine heterotrophic nanoflagellates on autotrophic picoplankton. J Plankton Res 19:1517-1536

Olson RJ, Chisholm SW, Zettler ER, Armbrust ER (1990) Pigments, size, and distribution of Synechococcus in the North Atlantic and Pacific Oceans. Limnol Oceanogr 35: 45-58

> Ortmann AC, Metzger RC, Liefer JD, Novoveska L (2011) Grazing and viral lysis vary for different components of the microbial community across an estuarine gradient. Aquat Microb Ecol 65:143-157

Pernthaler J (2005) Predation on prokaryotes in the water column and its ecological implications. Nat Rev Microbiol 3:537-546

Porter KG, Feig YS (1980) The use of DAPI for identifying and counting aquatic microflora. Limnol Oceanogr 25: 943-948

$>$ Pradeep Ram AS, Sime-Ngando T (2010) Resources drive trade-off between viral lifestyles in the plankton: evidence from freshwater microbial microcosms. Environ Microbiol 12:467-479

Proctor LM, Okubo A, Fuhrman JA (1993) Calibrating estimates of phage-induced mortality in marine bacteria: ultrastructural studies of marine bacteriophage development from one-step growth experiments. PSZN I Mar Ecol 25:161-182

Raven JA (1998) The twelfth Tansley Lecture. Small is beautiful: the picophytoplankton. Funct Ecol 12:503-513

Sanders RW, Berninger UG, Lim EL, Kemp PF, Caron DA (2000) Heterotrophic and mixotrophic nanoplankton predation on picoplankton in the Sargasso Sea and on Georges Bank. Mar Ecol Prog Ser 192:103-118

> Sherr EB, Sherr BF (2002) Significance of predation by protists in aquatic microbial food webs. Antonie van Leeuwenhoek 81:293-308

- Sime-Ngando T, Pradeep Ram AS (2005) Grazer effects on prokaryotes and viruses in a freshwater microcosm experiment. Aquat Microb Ecol 41:115-124

Steward GF, Wikner J, Cochlan WP, Smith DC, Azam F (1992) Estimation of virus production in the sea: II. Field results. Mar Microb Food Webs 6:79-90

Suttle CA (2000) Cyanophages and their role in the ecology of cyanobacteria. In: Whitton PM (ed) The ecology of cyanobacteria: their diversity in time and space. Kluwer Academic Publishers, Boston, MA, p 563-589

Suttle CA, Chan AM (1994) Dynamics and distribution of cyanophages and their effect on marine Synechococcus spp. Appl Environ Microbiol 60:3167-3174

> Taira Y, Uchimiya M, Kudo I (2009) Simultaneous estimation of viral lysis and protozoan grazing on bacterial mortality using a modified virus-dilution method. Mar Ecol Prog Ser 379:23-32

- Tsai AY, Chiang KP, Chang J, Gong GC (2005) Seasonal diel variations of picoplankton and nanoplankton in a subtropical Western Pacific coastal ecosystem. Limnol Oceanogr 50:1221-1231

Tsai AY, Chiang KP, Chang J, Gong GC (2008) Seasonal variations in trophic dynamics of nanoflagellates and 
picoplankton in coastal waters of the western subtropical Pacific Ocean. Aquat Microb Ecol 51:263-274

Tsai AY, Chin WM, Chiang KP (2009) Diel patterns of grazing by pigmented nanoflagellates on Synechococcus spp. in the coastal ecosystem of subtropical western Pacific. Hydrobiologia 636:249-256

Tsai AY, Gong GC, Sanders RW, Chen WH, Chao CF, Chiang KP (2011) Importance of bacterivory by pigmented and heterotrophic nanoflagellates during the warm season in a subtropical western Pacific coastal ecosystem. Aquat Microb Ecol 63:9-18

Vaulot D, Marie D (1999) Diel variability of photosynthetic picoplankton in the equatorial Pacific. J Geophys Res 104:3297-3310

> Wang K, Chen F (2004) Genetic diversity and population dynamics of cyanophage communities in the Chesapeake Bay. Aquat Microb Ecol 34:105-116

Waterbury JB, Watson SW, Valois FW, Franks DG (1986) Biological and ecological characterization of the marine unicellular cyanobacterium Synechococcus. In: Platt T, Li WKW (eds) Photosynthetic picoplankton. Can Bull Fish Aquat Sci 214:71-120

Weinbauer MG (2004) Ecology of prokaryotic viruses. FEMS Microbiol Rev 28:127-181

- Weinbauer MG, Peduzzi P (1994) Frequency, size and distri-

Editorial responsibility: Gunnar Bratbak,

Bergen, Norway bution of bacteriophages in different marine bacterial morphotypes. Mar Ecol Prog Ser 108:11-20

> Weinbauer MG, Christaki U, Nedoma A, Šimek K (2003) Comparing the effects of resource enrichment and grazing on viral production in a meso-eutrophic reservoir. Aquat Microb Ecol 31:137-144

> Weinbauer MG, Bonilla-Findji O, Chan AM, Dolan JR and others (2011) Synechococcus growth in the ocean may depend on the lysis of heterotrophic bacteria. J Plankton Res 33:1465-1476

Wilhelm SW, Brigden SM, Suttle CA (2002) A dilution technique for the direct measurement of viral production: a comparison in stratified and tidally mixed coastal waters. Microb Ecol 43:168-173

Winter C, Herndl GJ, Weinbauer MG (2004) Diel cycles in viral infection of bacterioplankton in the North Sea. Aquat Microb Ecol 35:207-216

> Worden AZ, Binder BJ (2003) Application of dilution experiments for measuring growth and mortality rates among Prochlorococcus and Synechococcus populations in oligotrophic environments. Aquat Microb Ecol 30:159-174

> Yuan X, Yin K, Harrison PJ, Zhang J (2011) Phytoplankton are more tolerant to UV than bacteria and viruses in the northern South China Sea. Aquat Microb Ecol 65: $117-128$

Submitted: November 10, 2011; Accepted: March 29, 2012

Proofs received from author(s): May 10, 2012 